\title{
Diet and ecomorphological relationships of four cichlid species from the Cuiabá River basin
}

\author{
Gisele C. Novakowski ${ }^{1}$, Fernanda A. S. Cassemiro ${ }^{2}$ and Norma S. Hahn ${ }^{3}$
}

Relationship between diet and morphology of cichlid were analyzed considering that the trophic apparatus determines differential food use among species. Cichlasoma dimerus and Satanoperca pappaterra showed a generalist diet, while Chaetobranchopsis australis and Crenicichla vittata consumed zooplankton and fish, respectively. Significant correlation between morphology and diet was not found, but $C$. australis differed from the others species in the upper mouth and longer gill rakers. The morphology data and food size segregated the cichlids into three groups. The first was comprised by $C$. australis, which has many and longer gill rakers and a more protractile mouth, the second by $C$. vittata, which have a larger and more-protruded mouth and the third by S. pappaterra and C. dimerus, with a smaller and lower mouth. The latter two groups have more widely spaced gill rakers and consumed larger food. Overall, our results showed different patterns of species grouping when considering morphological or diet data. However, to C. australis the gill rakers determine both the type and size of food.

A relação entre dieta e morfologia de ciclídeos foi analisada considerando que o aparato trófico determina o uso diferencial dos recursos alimentares entre as espécies. Cichlasoma dimerus e Satanoperca pappaterra, apresentaram dieta generalista, enquanto Chaetobranchopsis australis e Crenicichla vittata, consumiram zooplâncton e peixes, respectivamente. Nenhuma correlação significativa foi encontrada entre a morfologia e a dieta, entretanto, C. australis se distanciou das demais espécies, por apresentar boca superior e rastros branquiais longos e numerosos. Os dados de morfologia e tamanho do alimento consumido segregaram os ciclídeos em três grupos. O primeiro foi composto por C. australis, que possui rastros branquiais longos e numerosos, além de maior protractibilidade da boca, o segundo por $C$. vittata, que tem maior amplitude e protrusão da boca e o terceiro por S. pappaterra e C. dimerus que possuem boca pequena e inferior. Os dois últimos grupos apresentaram ainda, maior distância entre os rastros e consumiram alimentos maiores. Nossos resultados mostraram que, quando somente os dados morfológicos são considerados, as espécies foram agrupadas de forma diferente do que quando apenas os dados de dieta foram considerados. Entretanto, para C. australis os rastros branquiais determinam o tipo e tamanho do alimento.

Keywords: Cichlid fauna, Feeding, Food size, Pantanal, Trophic morphology.

\section{Introduction}

The diversity of feeding habits among fishes is the product of evolutionary processes that have led to several structural changes, due to the wide variety of environmental situations that these organisms are subject (Santos-Santos et al., 2015), and interactions among species (Lagler et al., 1977; Ruber \& Adams, 2001; Kocher, 2004). Evolutionary divergence can largely be considered a balance between selection and the mixing of organisms between alternative environments (Langerhans et al., 2003).
Several researchers have used ecomorphological patterns in an attempt to explain morphological variations of species over time, with the goal of establishing evolutionary parameters among those that are closely related (Winemiller, 1992; Meyer, 1993; Adite \& Winemiller, 1997; Langerhans et al., 2003). The ecomorphological approach, with a fairly high predictive power, is very useful when a rapid ecological assessment is required (Hugueny \& Pouilly, 1999). For fishes, the mouth opening is considered as one of the most important food intake characteristics, however other structures, including eye diameter and body height,

${ }^{1}$ Centro Universitário Ingá, Rodovia PR 317, 6114, 87035-510 Maringá, PR, Brazil.gcnovakowski@yahoo.com.br ${ }^{2}$ Systema Naturae Consultoria Ambiental, rua 58, 217, Jardim Goiás, 74810-250 Goiânia, GO, Brazil. fernandacassemiro@gmail.com ${ }^{3}$ Universidade Estadual de Maringá, Nupelia/DBI/PEA, Av. Colombo, 5790, 87020-900 Maringá, PR, Brazil. hahnns@nupelia.uem.br (corresponding author). 
head, and snout length (Ward-Campbell \& Beamish, 2005) and gill rakers (Schmitz \& Wainwright, 2011) can drive physical constraints on prey size. Another structure that has been studied is the pharyngeal jaws, which may impose a functional constraint on piscivory via pharyngeal gape in cichlids (Burress et al., 2015). In this way, the trophic ecology may be a key factor promoting morphological differentiation (Rüber \& Adams, 2001), allowing the coexistence of cichlid species, as seen in the African Great Lakes (Rüber \& Adams, 2001; Kassam et al., 2003).

The study of functional morphology is based on the concept that existing morphological differences (phenotype) in animals may be the result of strong environmental and biological pressures (Catella \& Petrere Jr, 1998; Casatti \& Castro, 2006). These selective pressures can favor specializations that maximize particular performances in specialists, adapting them to their trophic and habitat niches at each life stage (Santos-Santos et al., 2015). Thus, investigations on the relationship of the phenotype of a species to its use of the habitat can identify ecomorphological similarities between phylogenetically distant species (Chalcraft \& Resetarits Jr., 2003; Oliveira et al., 2010), or establish ecomorphological differences among closely related species (Winemmiler et al., 1995; Wainwright et al., 2002). Many fish, including representatives of the same family (Kassan et al., 2003; Sampaio et al., 2013) or the same genus (Russo et al., 2004; Balassa et al., 2004; Corrêa et al., 2009), may have different feeding habits and associated divergence in their feeding structures. Studies have also shown that the morphology and feeding habits vary, even among individuals of the same species that occupy different environments (Meyer, 1990; Turigan et al., 1995).

Fishes have provided a fertile field for the study of the relationship between form and function as a result of their long evolutionary history, high diversity and multiple life stages (Freire \& Agostinho, 2001). Inter- and intraspecific patterns of diet have often been compared to patterns of variation in the body shape, structure of the mouth (e.g., Delariva \& Agostinho, 2001; Wainwright et al., 2002) and other trophic apparatus like as gill rakers (Delariva \& Agostinho, 2001; López-Fernández et al., 2012).

Considering South America, the Cuiabá River basin has a representative cichlid fauna, composed by about 13 species (Verissimo et al., 2005). The sympatry of these species in this basin, besides high morphological and trophic diversity (Kullander et al., 2003; López-Fernández et al., 2014), defined our choice of this group. In this study, we analyzed the diet composition and trophic morphology of four species of cichlids, for which it was possible to obtain sufficient data. The studied species are the Chaetobranchini Chaetobranchopsis australis Eigenmann \& Ward, 1907, the Cichlasomatini Cichlasoma dimerus (Heckel, 1840) and the two Geophagini, Crenicichla vittata Heckel, 1840 and Satanoperca pappaterra (Heckel, 1840). Some studies about ecomorphology and/or diet of these species have been performed in other regions (Winemiler et al., 1995; Mérona
\& Rankin-de Mérona, 2004; Burress et al., 2013a). However, studies showing the relationship between the food size and the morphology of the gill rakers are poorly evaluated among cichlids. We test the hypothesis that the trophic apparatus determines differential food use among species. In order to evaluate interspecifics differences we seek to investigate: i) variation in diet, ii) the relationship between diet and trophic morphology, and iii) the importance of food size in predicting diet and trophic morphology.

\section{Material and Methods}

Study area. The Cuiabá River basin covers an area of approximately $9,365 \mathrm{~km}^{2}$, comprising the Cerrado and Pantanal regions of the state of Mato Grosso, which are important areas for species diversity, the Cerrado biome being considered one of the 34 world hotspots for conservation priority (Mittermeier et al., 2004). The Manso River cuts through a winding and enclosed valley, receiving other tributary streams on both banks. About 80 $\mathrm{km}$ downstream from its confluence with the Casca River, the Manso River joins with the Cuiabazinho River, forming the Cuiabá River, which then continues through lowland regions, flowing into the Pantanal (wetland) of Mato Grosso (Sondotécnica/Eletronorte, 1999).

Fish used in this study came from surveys performed at six sampling locations along the Cuiaba River basin. These six sites were chosen to maximize variation in environmental characteristics among habitats. We collected individuals from lotic (sites 2, 3 and 4) and lentic environments (sites 1, 5 and 6) (Fig. 1).

Sampling and data analysis. Collecting was performed monthly from April 2000 to March 2001, using gill nets with different mesh sizes ( 3.0 to $16 \mathrm{~cm}$ between opposite knots) and trawl nets, which were operated along the banks. The gill nets were displayed for $24 \mathrm{~h}$, and inspected in the morning, in the afternoon, and at night. Individuals were frozen and later fixed in $4 \%$ formaldehyde.

Voucher specimens are deposited at the Coleção de peixes do Núcleo de Pesquisas em Limnologia, Ictiologia e Aquicultura (Nupélia, Universidade Estadual de Maringá, Paraná State, Brazil): NUP 3476 - Chaetobranchopsis australis; NUP 0398 - Cichlasoma dimerus; NUP 3217 Crenicichla vittata and NUP 871 - Satanoperca pappaterra.

Fish specimens were dissected and the stomach contents were removed and fixed in $4 \%$ formaldehyde. Food items were identified under optical and stereoscopic microscopes. After identification, the volume of each item was estimated using a graduated cylinder for large items and a graduated plate for small items. Additionally, frequency of occurrence for each food item was used to calculate the Feeding Index values (IAi), according to Kawakami \& Vazzoler (1980). Thus, IAi was calculated as follows: IAi $=\% \mathrm{Fi} * \% \mathrm{Vi} /\left(\sum \% \mathrm{Fi}\right.$ $* \% \mathrm{Vi}$ ) x 100 , where: IAi = Feeding Index; Fi $=$ frequency of occurrence of the resource $i$ in the diet (\%); $\mathrm{Vi}=$ volume of the resource $i$ in the diet (\%). 


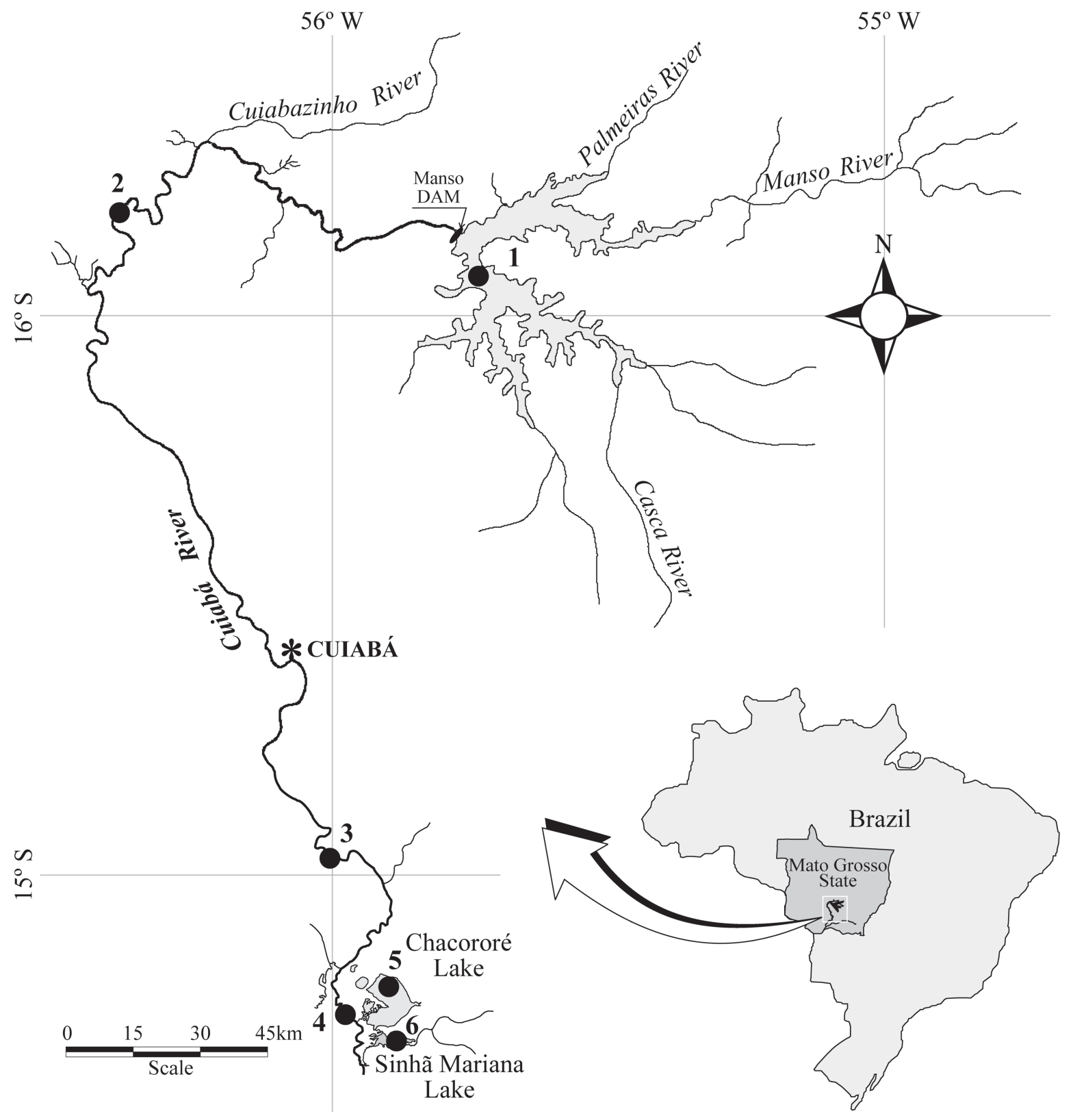

Fig. 1. Location of the Cuiabá River basin, Mato Grosso, Brazil, and the sampling sites: lotic (2, 3 and 4) and lentic (1, 5 and 6).

To avoid ontogenetic interference in the diet and morphology, gonads were removed and macroscopically analyzed to determine sexual maturity (immature/mature) according to Vazzoler (1996). Immature specimens were excluded of the analysis. The characters selected for the morphological measures were the position and shape of the mouth and the first gill arch on the right side. A digital caliper $(0.01 \mathrm{~mm})$ was used to measure the standard length (SL), height of the mouth (HM), width of the mouth (WM), orientation of the mouth $(\mathrm{OM})$, distance from the end of the lower jaw to the anterior border of the eye with the mouth closed (DMC), and the distance from the anterior end of the lower jaw to the anterior border of the eye with the mouth open (DMO) (Balon et al., 1986) (Fig. 2).
All measurements were taken linearly, except for the orientation of the mouth, which is defined by the angle formed between the plane tangent to the lips with the mouth open, and the horizontal axis of the body. Angle measuring between $10^{\circ}$ and $80^{\circ}$ characterize a superior mouth; approximately $90^{\circ}$, a terminal mouth; and between $100^{\circ}$ and $170^{\circ}$, an inferior mouth (Gatz, Jr.,1979). Based on these measurements, the following ecomorphological indices were calculated to size-corrections: relative height of the mouth (RHM $=\mathrm{HM} / \mathrm{SL})$ and relative width of the mouth (RWM $=\mathrm{WM} / \mathrm{SL})$. Also, the following ecomorphological ratio was calculated: protrusion of the mouth $(\mathrm{PM}=\mathrm{DMO} / \mathrm{DMC})$ (Watson \& Balon, 1984; Winemiller, 1991). 
To evaluate the relationships between diet and morphology, two dissimilarity matrices using the BrayCurtis Index and the UPGMA algorithm (average) were constructed. This index is suitable for relative or absolute abundance data. The arrays were made using the percentage of Feeding Index (IAi) versus the species (Trophic Matrix) and the ecomorphological attributes (RHM, SRGR, NGR, PM, RWM, DRG e OM) versus species (Morphology Matrix).

To test the null hypothesis that the diet similarity can be explained by the morphology, the Mantel test for comparisons of trophic matrices and morphology was used. The Mantel test measures the correlation between arrays of dissimilarity. The significance of the test was assessed using 10,000 random permutations.

A Zeiss Axiovision imaging system was used, together with an Axioskop 2 microscope and a Stemi SV 6 stereomicroscope, in order to estimate the food size (FS), as well as the size (SR) and distance (DR) among the gill rakers. The number of gill rakers of each species was also counted. To eliminate the influence of the size of the individuals on the size of the gill rakers, a measure of the raker size relative to the length of the respective gill (LG) was used, i.e., $\mathrm{SRGR}=\mathrm{SR} / \mathrm{LG}$ (Fig. 2).
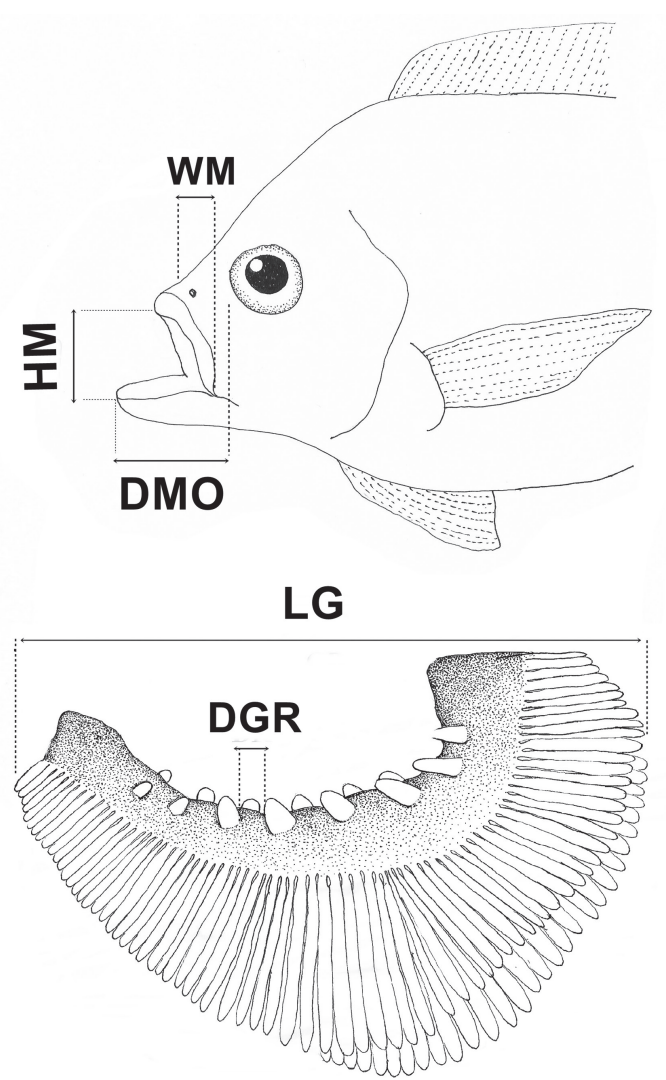

The relative size (SRGR), number (NGR) and distance of the gill raker (DR) data were initially analyzed for normality using the Kolmogorov Smirnov test and Levene's test for homogeneity of variance. After, we conducted univariate analyses (ANOVA) to examine SRGR, NGR and DR differences among fish species. Tests were considered 0.05 significance level followed by Tukey HSD post hoc test.

To emphasize variation and bring out patterns between the ecomorphological measurements (RHM, SRGR, NGR, PM, RWM, DRG and OM) and the food size (FS), a principal components analysis (PCA) on the correlation matrix between the ecomorphological measurements and the food size was performed. We adopted the analysis of the components whose eigenvalues are greater than 1 , because beginning with the lower values the influence of the residual variance increases, making analysis difficult (Legendre \& Legendre, 1998).

To identify the effect of the morphological variables (predictors) on the food size (response variable), a stepwise multiple linear regression was used according to Bayesian methodology (Rossi, 2011), conducted using the software WinBugs (Lunn et al., 2000). All other analyses were conducted using the statistical package $\mathrm{R}$ version 3.0.2 ( $\mathrm{R}$ Core Team, 2013).

Fig. 2. Representation of ecomorphological measurements taken for four species of cichlids of the Cuiabá River basin, Mato Grosso, Brazil. $\mathrm{OM}=$ orientation of the mouth opening; $\mathrm{HM}=$ height of the mouth; $\mathrm{WM}=$ width of the mouth; $\mathrm{DMO}=$ distance from the anterior end of the jaw to anterior border of the eye, with the mouth open; DMC = distance from the end of the jaw to anterior border of the eye, with the mouth closed; $L G=$ length of the gill; $D G R=$ distance between the gill rakers; $\mathrm{SL}=$ standard length. 


\section{Results}

Diet composition and trophic morphology. The diet and the trophic matrix showed a group consisting of Cichlasoma dimerus and Satanoperca pappaterra, which were generalists, consuming similar proportions of insects, plants and detritus. Chaetobranchopsis australis and Crenicichla vittata showed specialized diets and diverged from the other species, with about 97\% dissimilarity. For C. australis, microcrustaceans comprised nearly $100 \%$ of the diet, and for C. vittata, fish comprised more than $90 \%$ of the diet (Table 1, Fig. 3). The morphological matrix generated a group with more that $95 \%$ similarity: $C$. dimerus and $C$. vittata. With these species, S. pappaterra showed about $90 \%$ similarity and $C$. australis showed the most distinct morphological variables, with about $70 \%$ similarity to the other species (Fig. 3).

Table 1. Percentages (IAi) of food resources consumed by four species of cichlids from the Cuiabá River basin, Mato Grosso, Brazil. $n=$ number of stomachs. $\mathrm{SL}=$ standard length. $C$. australis $=$ Chaetobranchopsis australis; $C$. dimerus $=$ Cichlasoma dimerus; C. vittata $=$ Crenicichla vittata; S. pappaterra $=$ Satanoperca pappaterra.

\begin{tabular}{lcccc}
\hline Food Sources & C. australis & C. dimerus & C. vittata & S. pappaterra \\
& $n=21$ & $n=26$ & $n=17$ & $n=47$ \\
\hline Algae & 0.05 & 0.88 & & 0.34 \\
Plants & 1.07 & 24.19 & 0.22 & 24.62 \\
Annelids & 0.06 & & & 1.61 \\
Microcrustaceans & 98.42 & & 0.03 & 0.99 \\
Aquatic insects & & 23.28 & 1.62 & 20.55 \\
Terrestrial insects & & 28.17 & & \\
Insect remains & & 11.04 & 0.03 & 0.53 \\
Scales & 0.06 & 4.60 & & 11.99 \\
Fish & & 1.45 & 98.08 & \\
Detritus/sediment & 0.34 & 6.39 & 0.02 & 39.37 \\
\hline SL (cm) & $7.1-11.8$ & $5.5-9.0$ & $12.1-27.2$ & $10.0-12.8$ \\
\hline
\end{tabular}

Cichlasoma dimerus and C. vittata have a terminal mouth $\left(\mathrm{OM} \approx 90^{\circ}\right)$, whereas $C$. australis and $S$. pappaterra have superior $(\mathrm{OM}<80)$ and inferior $(\mathrm{OM}>100)$ mouths, respectively. The lips are more developed in $C$. vittata and S. pappaterra.

Species differ as to the relative size $\left(\mathrm{F}_{4,18}=847.7968 ; \mathrm{p}<\right.$ $0.05)$, number $\left(\mathrm{F}_{4,18}=1763.1197 ; \mathrm{p}<0.05\right)$ and distance of the gill rakers $\left(\mathrm{F}_{4.18}=103.94 ; \mathrm{p}<0.05\right)$. Chaetobranchopsis australis has the largest amount and the longest and most closely spaced gill rakers, whereas $C$. dimerus and $S$. pappaterra have the shortest. The widest spacing between the rakers was observed in C. vittata. Satanoperca pappaterra is the only species that has an epibranchial lobe (Fig. 4).
Bray-Curtis Dissimilarity - Trophic Matrix

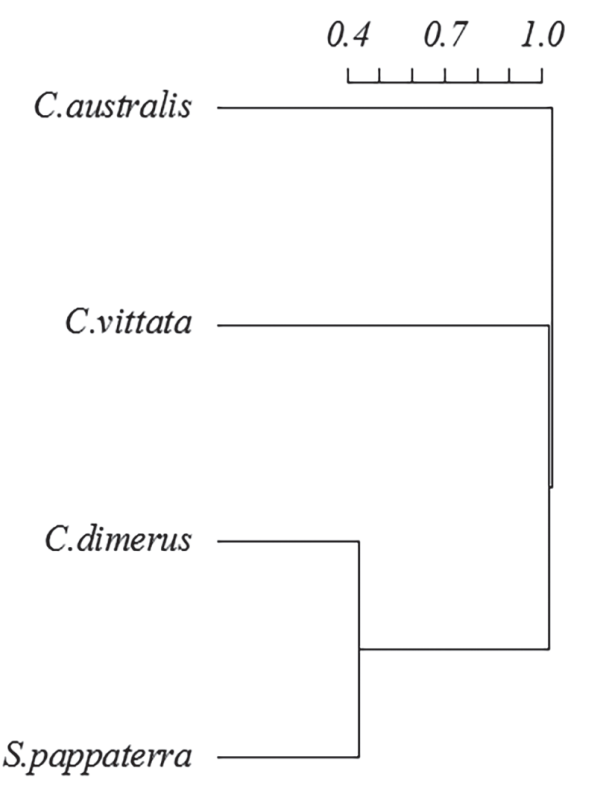

Bray-Curtis Dissimilarity - Morphology Matrix

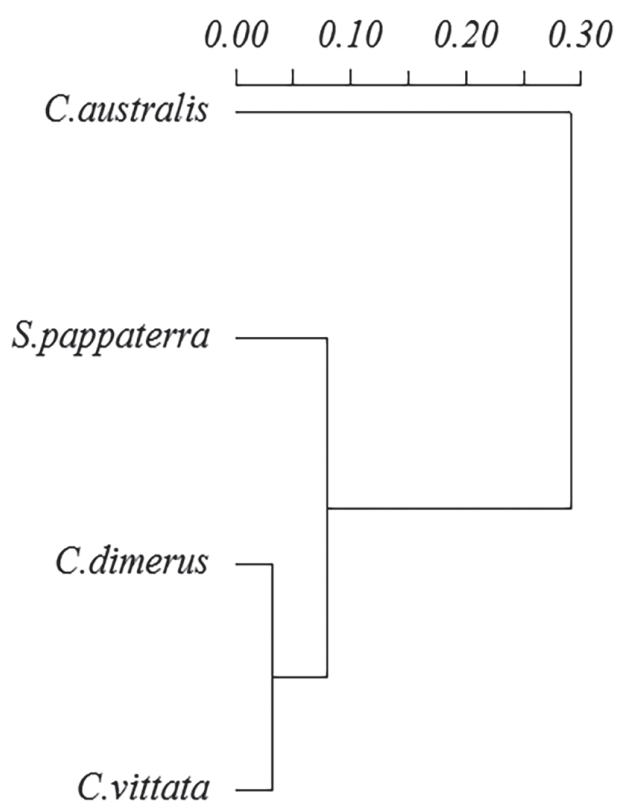

Fig. 3. Dendrogram of Bray-Curtis dissimilarity for the trophic matrix (percentage of IAi of the food resources versus species) and morphologic matrix (RHM, SRGR, NGR, PM, RWM, DRG, OM versus species) of the cichlids of the Cuiabá River basin, Mato Grosso, Brazil. IA $=$ Feeding Index; RHM = Relative height of the mouth; SRGR = Relative size of the gill rakers; NGR $=$ Number of gill rakers; $\mathrm{PM}=$ Protrusion of the mouth; RWM = Relative width of the mouth; DRG = Distance between gill rakers; $\mathrm{OM}=$ Orientation of the mouth. $C$. australis = Chaetobranchopsis australis; C. dimerus $=$ Cichlasoma dimerus; $C$. vittata $=$ Crenicichla vittata; S. pappaterra $=$ Satanoperca pappaterra. 

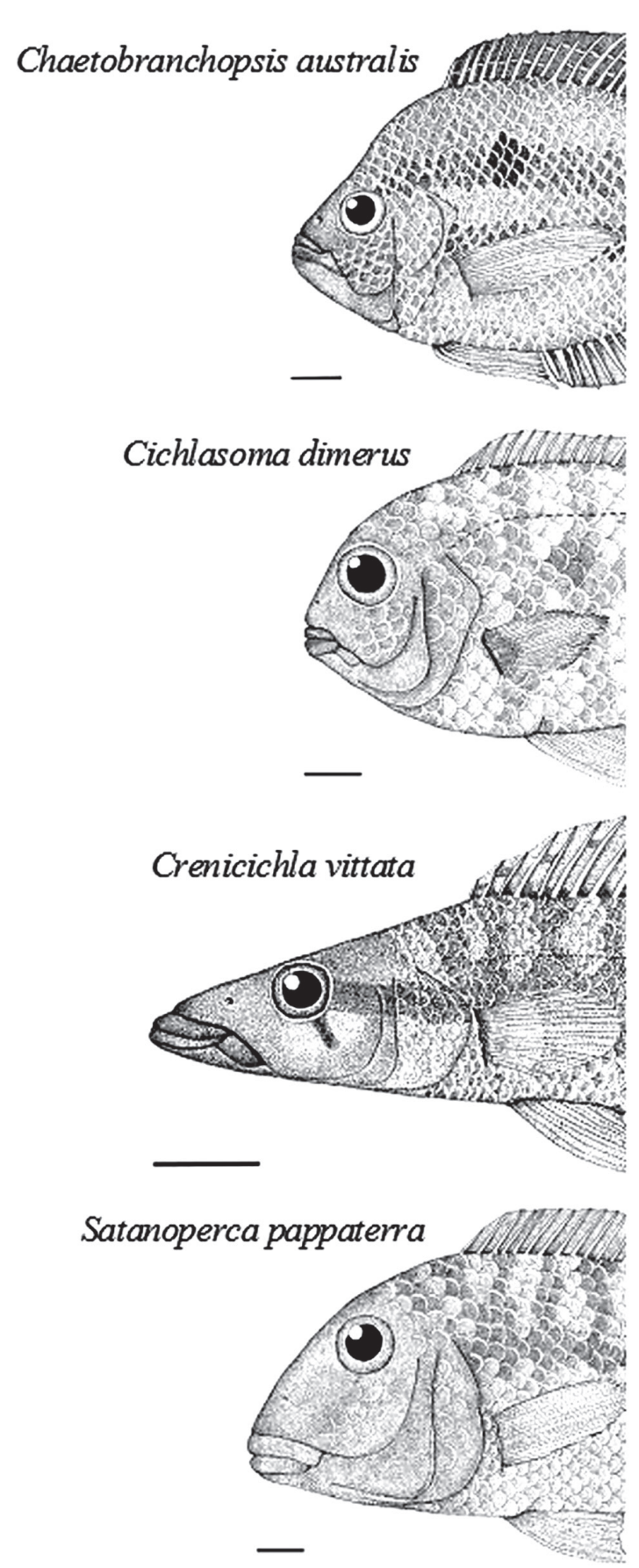
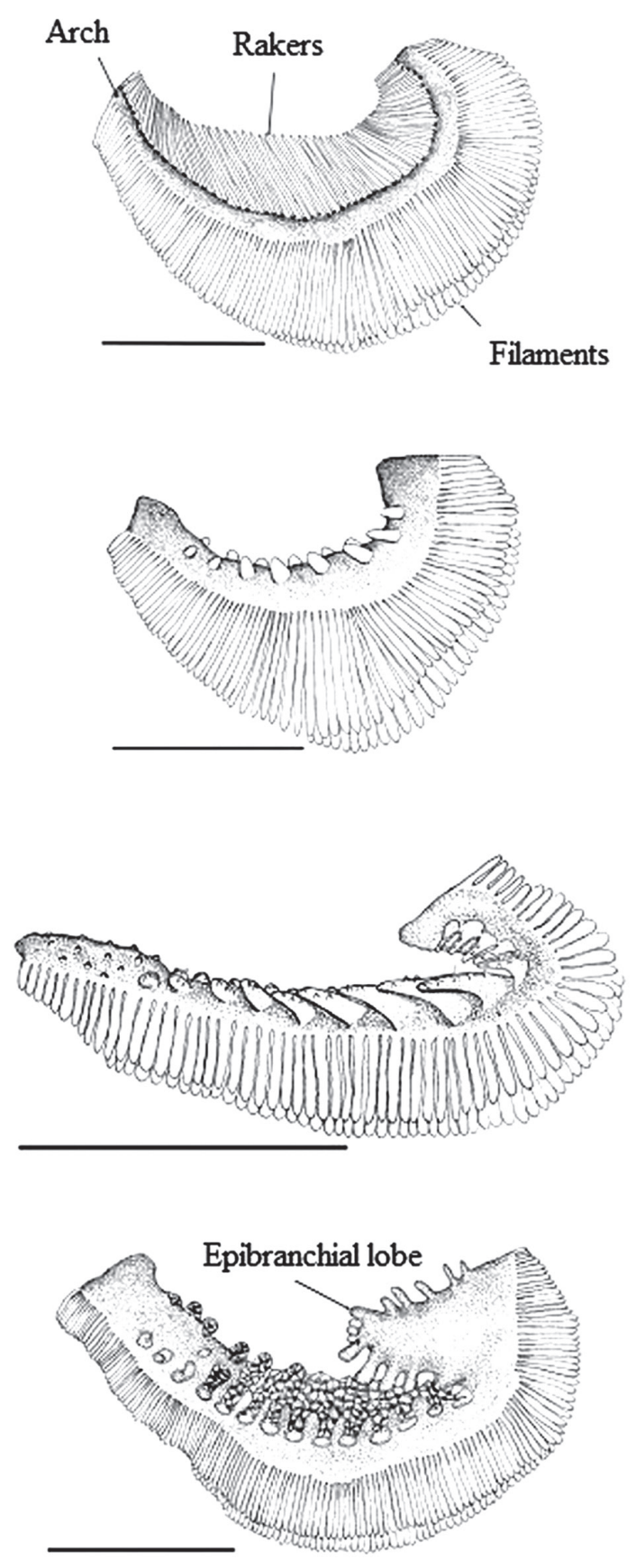

Fig. 4. Position and shape of the mouth, and first pair of gill raker of cichlids from the Cuiabá River basin, Mato Grosso, Brazil. Scale $=1 \mathrm{~cm}$. (drawing by Gisele C. Novakowski).

Relationship between diet and morphology. Trophic and morphology matrices did not show a significant correlation $(\mathrm{r}$ $=0.42 ; \mathrm{p}=0.20$ ), supporting the lack of association between morphology and diet. The Principal Component Analysis, applied on the morphological data and food size, explained $74 \%$ (axes 1) and $22 \%$ (axes 2 ) of the total variability of the data. On the first axis, the most important attributes with negative loadings were the number and relative size of the gill rakers and the relative height and width of the mouth. Food size and distance between gill rakers were the variables that better discriminated species with positive loadings. Thus, $C$. australis showed negative loadings, in response to the longer and more numerous gill rakers. The other species showed positive loadings, with greater distances between the rakers and that consume larger food. On the second axis $C$. vittata, with positive loadings, were segregated in response to higher values of relative height of the mouth. The orientation of the mouth with negative loadings discerned $S$. pappaterra and $C$. dimerus which have angle of the jaw $>90^{\circ}$ (Table 2, Fig. 5). 
Only the distance between the gill rakers (DR) was not significant for the multiple regression model, indicating that the other measurements are sufficient to explain the food size (Table 3).

Table 2. Eigenvectors of the principal components analysis (PCA), with the first axis representing the principal component 1 (PC1) and the second axis the principal component 2 (PC2) calculated from the food size and the morphological variables of cichlids of the Cuiabá River basin, Mato Grosso, Brazil. In bold: eigenvectors that contributed most positively and negatively to the formation of the axes.

\begin{tabular}{lcc}
\hline Variables & PC 1 & PC 2 \\
\hline Orientation of the mouth (OM) & 0.32 & -0.32 \\
Relative width of the mouth (RWM) & -0.31 & $\mathbf{- 0 . 4 7}$ \\
Relative height of the mouth (RHM) & $\mathbf{- 0 . 3 5}$ & 0.35 \\
Number of gill rakers (NGR) & $\mathbf{- 0 . 4 0}$ & 0.05 \\
Relative size of the gill rakers (SRGR) & $\mathbf{- 0 . 4 0}$ & 0.13 \\
Distance between gill rakers (DGR) & 0.33 & $\mathbf{0 . 4 3}$ \\
Protrusion of the mouth (PM) & -0.34 & $\mathbf{0 . 3 6}$ \\
Food size (FS) & 0.32 & $\mathbf{0 . 4 3}$ \\
Eigenvalues & 2.34 & 1.46 \\
Variance explained \% & 74.35 & 22.78 \\
Total variance & & 97.13 \\
\hline
\end{tabular}

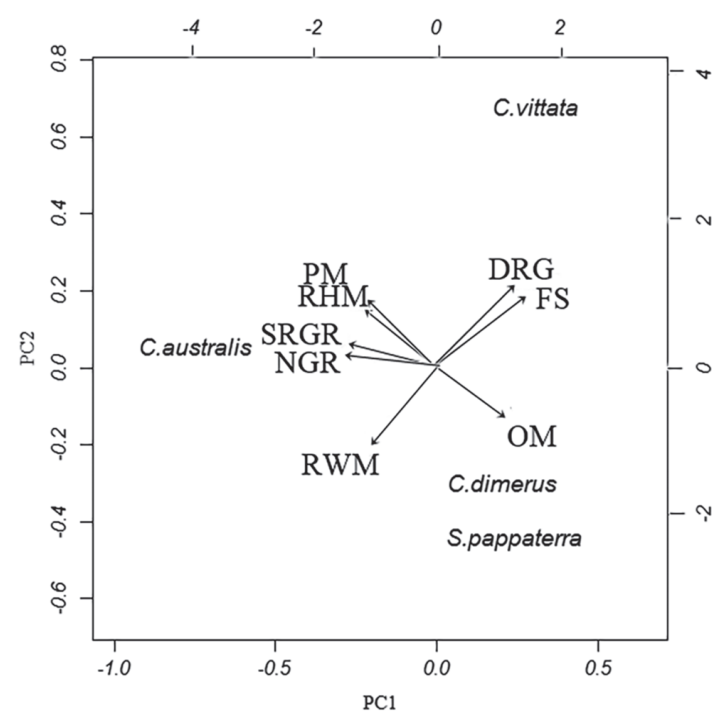

Fig. 5. Projections of the scores on axes 1 (PC1) and 2 (PC2) of the principal components analysis performed with values of the morphological attributes and food size consumed by four species of cichlids from the Cuiabá River basin, Mato Grosso, Brazil. Variance explained: $\mathrm{PC} 1=68.55 \%$; $\mathrm{PC} 2=26.73 \%$. Abbreviations are in Table 2. C. australis = Chaetobranchopsis australis; C. dimerus = Cichlasoma dimerus; $C$. vittata $=$ Crenicichla vittata; S. pappaterra $=$ Satanoperca pappaterra.

Table 3. Ecomorphological parameters estimated according to the multiple regression analysis for cichlids species from the Cuiabá River basin, Mato Grosso, Brazil. $\mathrm{R}^{2}=$ linear correlation coefficient. $\mathrm{OM}=$ orientation of the mouth, $\mathrm{RWM}=$ relative width of the mouth, RHM = relative height of the mouth, NGR = number of gill rakers, $S R G R=$ relative size of the gill rakers, $\mathrm{DGR}=$ distance between the gill rakers, $\mathrm{PM}=$ protrusion of the mouth. $\mathrm{SD}=$ standard deviation, $\mathrm{MC}$ error $=$ Monte Carlo error.

\begin{tabular}{ccccccccc}
\hline Parameter & Mean & SD & MC error & $2.5 \%$ & Median & $97.5 \%$ & Begin & Sample \\
\hline OM & 0.334 & 0.16 & 0.001 & 0.016 & 0.335 & 0.651 & 1000 & 10001 \\
RWM & -0.386 & 0.15 & 0.001 & -0.692 & -0.387 & -0.077 & 1000 & 10001 \\
RHM & -0.183 & 0.06 & $4.16 \mathrm{E}-4$ & -0.307 & -0.183 & -0.06 & 1000 & 10001 \\
NGR & 0.521 & 0.09 & $6.78 \mathrm{E}-4$ & 0.339 & 0.521 & 0.705 & 1000 & 10001 \\
SRGR & -0.242 & 0.07 & $5.5 \mathrm{E}-4$ & -0.396 & -0.242 & -0.09 & 1000 & 10001 \\
DGR & -0.021 & 0.02 & $1.9 \mathrm{E}-4$ & -0.075 & -0.021 & 0.031 & 1000 & 10001 \\
PM & -0.034 & 0.01 & $1.05 \mathrm{E}-4$ & -0.066 & -0.034 & -0.003 & 1000 & 10001 \\
R & 0.75 & 0.11 & 0.002 & 0.449 & 0.78 & 0.89 & 1000 & 10001 \\
\hline
\end{tabular}

\section{Discussion}

The four species of cichlids exploited a variety of food resources and diverged in their diets. The two species with the closest values of feeding similarity, Cichlasoma dimerus and Satanoperca pappaterra, differed in relation to the predominant food type consumed. Cichlasoma dimerus consumed mainly plants and aquatic and terrestrial insects whereas $S$. pappaterra consumed a combination of aquatic insects, plants and detritus. The high consumption of detritus by $S$. pappaterra indicates that this species is a bottom dwelling feeder, as reported by some authors (Hahn \& Cunha, 2005; Pelicice \& Agostinho, 2006), while C. dimerus appears to feed mainly in the pelagic zone. In addition, Chaetobranchopsis australis and Crenichla vittata showed more-divergent diets, consuming zooplankton and fish, respectively. Chaetobranchopsis australis, is already known to be zooplantivorous (Winemiller et al., 1995; Mérona \& Rankin de Mérona, 2004), while $C$. vittata and other species of the same genus are known to be piscivorous (Burress et al., 2013a, 2013b, 2015). Among Crenicichla species (adult individuals), the piscivory degree varies between primary piscivorous (eat only fishes) and secundary piscivorous (eat macroinvertebrates and fishes) (Burress et al., 2013a, 2013b, 2015). In this study, C. vittata can be considered primary piscivorous, although the number of analyzed stomachs has been restricted. 
The position of the mouth can be associated with the location of preferred prey in the water column (i.e., Balassa et al., 2004; Hahn \& Cunha, 2005; López-Fernández et al., 2014), being that fish with a terminal mouth are apparently not restricted in acquiring food, as in the case of $C$. dimerus and $C$. vittata. On the other hand, $C$. australis, with a superior mouth, consumed food from the planktonic regions, and $S$. pappaterra, with an inferior mouth, exploited the benthic region. Crenicichla vittata and $S$. pappaterra possess protruding lips, equipped with taste buds (sensu Gerking, 1994). To S. pappaterra, these taste buds should be used to grope food in the substrate where vision has a small role due to the low light conditions. Cassemiro et al. (2008) reported that this species is not a good visual predator, and as a bottom-dweller, it must use other senses to detect food, such as smell. According to López-Fernández et al. (2014), species with larger gapes, such as Satanoperca spp., may be more efficient winnowers of invertebrates embedded within sediments.

There is a close relationship between the food size and spacing of the gill rakers, because the function of the gill rakers is to help retain captured prey in zooplankton (Schmitz \& Wainwright, 2011). Thus, the longer and closer together are the gill rakers, the smaller the food size, and this relationship was observed in C. australis. Numerous and long rakers are characteristic of Chaetobranchini and this anatomical adaptation allowed these fishes to efficiently retain and process zooplankton (Kullander \& Nijssen, 1989; Winemiller et al., 1995; Mérona \& Rankin de Mérona, 2004). In the same way, shorter gill rakers are associated with smaller food sized as observed to $S$. pappaterra and $C$. dimerus. These findings suggest that similar feeding performance among benthonic consumer cichlids reflects constraints associated with functional morphology. Although, considering the diet composition, $S$. pappaterra proved to be a better consumer of benthic resources than $C$. dimerus, this species has another trophic specialization represented by the epibranquial lobe. The epibranchial lobe is an antero-ventral expansion of the first epibranchial bone capped with cartilage and lined with padlike gill rakers. It has been hypothesized that this structure is either an adaptation for mouth brooding or for sifting of substrate and food particles (see López-Fernández et al., 2012). In fact, this functionality applies to $S$. pappaterra, which during feeding expels unpalatable items through the mouth and operculum (Casatti et al., 2003). This structure is the unique trait of the Geophagini (López-Fernández et al., 2012).

Crenicichla vittata and $C$. dimerus were the most similar species in relation to trophic morphology. Nevertheless, very close to these two species was positioned $S$. pappaterra, which in spite of sharing some characters with the species above, show a smaller relative mouth height. Chaetobranchopsis australis was distinguished from the other species based on the greater length and closer spacing of the gill rakers, a feature found only in this species.
Relationships between diet and morphology of the species were not significant, since some characteristics were more important than others in obtaining food. As an example of this, $C$. australis showed many trophic attributes, whose mouth position, size and width between gill rakers restricted the type of food ingested, characterizing it as a trophic specialist (Gerking, 1994), with a diet based essentially on zooplankton, characteristic of the Chaetobranchini, as already mentioned. The cichlid Ctenopharynx pictus (Trewavas, 1935), from Lake Malawi, is an example of the capacity of the gill rakers to process ingested items differentially by size. Although this species has a large mouth, consuming large volumes of food, the gill rakers allow selection of small prey such as copepods, and the exclusion of accidentally ingested sediment (Ribbink et al., 1983). Constraints imposed by head morphology limit the type of prey that $S$. pappaterra is able to consume efficiently on the substrate. Therefore, its feeding habit is compatible with the inferior mouth and short gill rakers.

The PCA segregated the species according to the food size ingested. The first axis was influenced by the characteristics of the gill rakers, mouth size and food size, and for this reason separated at extremes the planktivorous species $(C$. australis) from $C$. vittata, which have a larger mouth and larger food in the diet. The second axis was influenced by the position and height of the mouth, distancing $S$. pappaterra and $C$. dimerus from the other species as a function of their mouths, which are smaller in height and have angles $<90^{\circ}$. The results showed an interspecific divergence related to the diet, although the trophic morphology only partly explained the feeding strategies. Morphological characters, principally related to the gill rakers and position of the mouth, were more predictive, explaining the type of food ingested; however, most of them showed only a weak association with the diet. However, considering the food size ingested, it is evident that the species are segregated in accordance with their morphology, especially with the characters related to the mouth. Overall, our results showed different patterns of species grouping when considering morphological or diet data. For this reason, the species diet probably can be more related to the food availability than to trophic morphology. However, with $C$. australis, the gill rakers determine the type and size of the food consumed.

\section{Acknowledgements}

We express our appreciation to Nupélia (Núcleo de Pesquisas em Limnologia, Ictiologia e Aquicultura), to Furnas Centrais Elétricas and to PEA (Programa de Pós-graduação em Ecologia de Ambientes Aquáticos Continentais) for their financial support and infrastructure and $\mathrm{CNPq}$ (Conselho Nacional de Pesquisa) in terms of personal grants to the last author (Proc. 302693/2013-0). The anonymous reviewers greatly helped to improve this paper. The English language been revised by Janet W. Reid (Virginia Museum of Natural History). 


\section{References}

Adite, A. \& K. O. Winemiller. 1997. Trophic ecology and ecomorphology of fish assemblages in coastal lakes of Benin, West Africa. Ecoscience, 4: 6-23.

Balassa, G. C., R. Fugi, N. S. Hahn \& A. B. Galina. 2004. Dieta de espécies de Anostomidae (Teleostei, Characiformes) na área de influência do reservatório de Manso, Mato Grosso, Brasil. Iheringia, 94: 77-82.

Balon, E. K., S. S. Crawford \& A. Lelek. 1986. Fish communities of the upper Danube River (Germany, Austria) prior to the new Rhein-Main-Donan connection. Environmental Biology of Fishes, 15: 243-271.

Burress, E. D., A. Duarte, W. S. Serra, M. Loureiro, M. M. Gangloff \& L. Siefferman. 2013a. Functional diversification within a predatory species flock. PloS One 8: e80929.

Burress, E. D., A. Duarte, W. S. Serra, M. M. Gangloff \& L. Siefferman. 2013b. Species-specific ontogenetic diet shifts among Neotropical Crenicichla: using stable isotopes and tissue stoichiometry. Journal of Fish Biology, 82: 1904-1915.

Burress, E. D., A. Duarte, W. S. Serra \& M. Loureiro. 2015. Rates of piscivory predict pharyngeal jaw morphology in a piscivorous lineage of cichlid fishes. Ecology of Freshwater Fish, Doi:10.1111/eff.12236.

Casatti, L. \& R. M. C. Castro. 2006. Testing the ecomorphological hypothesis in a headwater riffles fish assemblage of the rio São Francisco, southeastern Brazil. Neotropical Ichthyology, 4: 203-214.

Casatti, L., H. F. Mendes \& K. M. Ferreira. 2003. Aquatic macrophytes as feeding site for small fishes in the Rosana Reservoir, Paranapanema River, Southeastern Brazil. Brazilian Journal of Biology, 63: 213-222.

Cassemiro, F. A. S., T. F. L. V. B. Rangel, F. M. Pelicice \& N. S. Hahn. 2008. Allometric and ontogenetic patterns related to feeding of a neotropical fish, Satanoperca pappaterra (Perciformes, Cichlidae). Ecology of Freshwater Fish, 17: 155-164.

Catella, A. C. \& M. Petrere Jr. 1998. Body shape and food habits of fish from baia da Onça, a Pantanal floodplain lake. Verhandlungen der Internationalen Vereinigung für Theoretische und Angewandte Limnologie, 26: 2203-2208.

Chalcraft, D. R. \& W. J. Resetarits Jr. 2003. Mapping functional similarity of predators on the basis of trait similarities. American Naturalist, 162: 390-402.

Corrêa, C. E., N. S. Hahn \& R. L. Delariva. 2009. Extreme trophic segregation between sympatric fish species: the case of small sized body Aphyocharax in the Brazilian Pantanal. Hydrobiologia, 635: 57-65.

Delariva, R. L. \& A. A. Agostinho. 2001. Relationship between morphology and diets of six neotropical loricariids. Journal of Fish Biology, 58: 832-847.

Freire, A. G., \& A. A. Agostinho. 2001. Ecomorfologia de oito espécies dominantes da ictiofauna do reservatório de Itaipu (Paraná/Brasil). Acta Limnologica Brasiliensia, 13: 1-9.

Gatz, Jr., A. J. 1979. Ecological morphology of freshwater stream fishes. Tulane Studies in Zoology and Botany, 21: 91-124.

Gerking, S .D. 1994. Feeding Ecology of Fish. San Diego, Academic Press, Inc., 416p.
Hahn, N. S. \& F. Cunha. 2005. Feeding and trophic ecomorphology of Satanoperca pappaterra (Pisces, Cichlidae) in the Manso Reservoir, Mato Grosso State, Brazil. Brazilian Archives of Biology and Technology, 48: 1007-1012.

Hugueny, B. \& M. Pouilly. 1999. Morphological correlates of diet in an assemblage of West African freshwater fishes. Journal of Fish Biology, 54: 1310-1325.

Kassan, D. D., D. C. Adams, J. D. Aggrey, A. J. D. Ambali \& K. Yamaoka. 2003. Body shape variation in relation to resource partitioning within cichlid trophic guilds coexisting along the rocky shore of Lake Malawi. Animal Biology, 53: 59-70.

Kawakami, E. \& G. Vazzoler. 1980. Método gráfico e estimativa de índice alimentar aplicado no estudo de alimentação de peixes. Boletim do Instituto Oceanográfico, 29: 205-207.

Kocher, T. D. 2004. Adaptive evolution and explosive speciation: the cichlid fish model. Nature Reviews Genetics, 5: 288-298.

Kullander, S. O. 2003. Family Cichlidae. Pp. 605-654. In: Reis, R. E., S. O. Kullander \& C. J. Ferraris Jr. (Eds.). Check list of the freshwater fishes of South and Central America. Porto Alegre, Edipucrs.

Kullander, S. O. \& H. Nijssen. 1989. The Cichlids of Surinam: Teleostei, Labroidei. Brill.

Lagler, K. F., J. E. Bardach, R. R. Miller \& D. R. M. Passino. 1977. Ichthyology. New York, John Wiley and Sons, Inc., $528 \mathrm{p}$.

Langerhans, R. B., C. A. Layman, A. K. Langerhans \& T. J. Dewitt. 2003. Habitat-associated morphological divergence in two Neotropical fish species. Biological Journal of the Linnean Society, 80: 689-698.

Legendre, P. \& L. Legendre. 1998. Numerical Ecology. 2nd ed. Amsterdam, Elsevier,853p.

López-Fernández H., J. Arbour, S. Willis, C. Watkins, R. L. Honeycutt \& K. O. Winemiller. 2014. Morphology and efficiency of a specialized foraging behavior, sediment sifting, in Neotropical cichlid fishes. PLoS ONE, 9: e89832.

López-Fernández, H., K. O. Winemiller, C. Montaña \& R. L. Honeycutt. 2012. Diet-morphology correlations in the radiation of South American Geophagine Cichlids (Perciformes: Cichlidae: Cichlinae). PLoS ONE, 7: e33997.

Mérona, B. D. \& J. Rankin-de-Mérona. 2004. Food resource partitioning in a fish community of the central Amazon floodplain. Neotropical Ichthyology, 2: 75-84.

Meyer, A. 1990. Morphometrics and allometry in the trophically polymorphic cichlid fish, Cichlasoma citrinellum: alternative adaptations and ontogenetic changes in shape. Journal of Zoology, 221: 237-260.

Meyer, A. 1993. Phylogenetic relationships and evolutionary processes in East African cichlid fishes. Trends in Ecology \& Evolution, 8: 279-284.

Mittermeier, R. A., P. R. Gil, M. Hoffmann, J. Pilgrim, T. Brooks, C. G. Mittermeier, J. Lamoreux \& G. A. B. Fonseca. 2004. Hotspots revisited - Earth's biologically richest and most endangered terrestrial ecoregions. Mexico City; Washington D.C., Conservation International in collaboration with CEMEX Books on Nature Series, Agrupacion Sierra Madre, and the University of Virginia, 392p. 
Oliveira, E. F., E. Goulart, L. Breda, C. V. Minte-Vera, L. R. S. Paiva \& M. R. Vismara. 2010. Ecomorphological patterns of the fish assemblage in a tropical floodplain: effects of trophic, spatial and phylogenetic structures. Neotropical Ichthyology, 8: 569-586.

Pelicice, F. M. \& A. A. Agostinho. 2006. Feeding ecology of fishes associated with Egeria spp. patches in a tropical reservoir, Brazil. Ecology of Freshwater Fish, 15: 10-19.

R Development Core Team. 2013. R: a language and environment for statistical computing. $\mathrm{R}$ Foundation for Statistical Computing, Vienna, Austria. Available from http://www.Rproject.org/.

Ribbink, A. J., B. A. Marsh, A. C. Marsh, A. C. Ribbink \& B. J. Sharp. 1983. A preliminary survey of the cichlids of rocky habitats in Lake Malawi. South African Journal of Zoology, 18: 149-310.

Rossi, R. M. 2011. Introdução aos métodos Bayesianos na análise de dados zootécnicos com uso do WinBUGS e R. Maringá, Eduem, 191p.

Rüber, L. \& D. C. Adams. 2001. Evolutionary convergence of body shape and trophic morphology in cichlids from Lake Tanganyika. Journal of Evolutionary Biology, 14: 325-332.

Russo, M. R., N. S. Hahn \& C. S. Pavanelli. 2004. Resource partitioning between two species of Bryconamericus Eigenmann, 1907 from the Iguaçu river basin, Brazil. Acta Scientiarum Biological Sciences, 26: 431-436.

Sampaio, A. L. A., J. P. A. Pagotto \& E. Goulart. 2013. Relationship between morphology, diet and spatial distribution: testing the effects of intra and interspecific morphological variations on the patterns of resource use in two Neotropical Cichlids. Neotropical Ichthyology, 11: 351-360.

Santos-Santos, J. H., L. Audenaert, E. Verheyen \& D. Adriaens. 2015. Divergent ontogenies of trophic morphology in two closely related Haplochromine cichlids. Journal of Morphology, 276: 860-871.

Schmitz, L. \& P. C. Wainwright. 2011. Ecomorphology of the eyes and skull in zooplanktivorous labrid fishes. Coral Reefs, 30: 415-428.
Sondotécnica/Eletronorte. 1999. Levantamento da infraestrutura das colônias de pescadores sob a área de influência do APM Manso. Programa 08, Ictiofauna (relatório técnico).

Lunn, D. J., A. Thomas, N. Best \& D. Spiegelhalter. 2000. WinBUGS - a Bayesian modelling framework: concepts, structure, and extensibility. Statistics and Computing, 10: 325-337.

Turigan, R. G., P. C. Wainwright \& D. A. Hensley. 1995. Interpopulation variation in prey use feeding biomechanics in Caribbean triggerfishes. Oecologia, 102: 296-304.

Vazzoler A. E. A. M. 1996 Biologia da reprodução de peixes teleósteos: teoria e prática. Maringá, EDUEM, 169p.

Veríssimo, S., C. S. Pavanelli, H. A. Britski \& M. M. M. Moreira. 2005. Fish, Manso Reservoir region of influence, Rio Paraguai basin, Mato Grosso State, Brazil. Check List, 1: 1-9.

Wainwright, P. C., D. R. Bellwood \& M. W. Westneat. 2002. Ecomorphology of locomotion in labrid fishes. Environmental Biology of Fishes, 65: 47-62.

Ward-Campbell, B. M. S. \& F. W. H. Beamish. 2005. Ontogenetic changes in morphology and diet in the snakehead, Channa limbata, a predatory fish in western Thailand. Environmental Biology of Fishes, 72: 251-257.

Watson, D. J. \& E. K. Balon. 1984. Ecomorphological analysis of fish taxocenes in rainforest streams of northern Borneo. Journal of Fish Biology, 25: 371-384.

Winemiller, K. O. 1991. Ecomorphological diversification in lowland freshwater fish assemblages from five biotic regions. Ecological Monographs, 61: 343-365.

Winemiller, K. O. 1992. Ecomorphology of freshwater fishes. National Geographic Research \& Exploration, 8: 308-327.

Winemiller, K. O., L. C. Kelso-Winemiller \& A. L. Brenkert. 1995. Ecomorphological diversification and convergence in fluvial cichlid fishes. Environmental Biology of Fishes, 44: 235-261.
Submitted September 23, 2015

Accepted May 27, 2016 by Carmen Montaña 